\title{
Fast Anxiolytic-Like Effect Observed in the Rat Conditioned Defensive Burying Test, after a Single Oral Dose of Natural Protein Extract Products
}

\author{
Thomas Freret $^{1,2, *(\mathbb{D})}$, Stacy Largilliere ${ }^{1}$, Gerald Nee ${ }^{1}$, Melanie Coolzaet ${ }^{1}$, Sophie Corvaisier ${ }^{1}$ \\ and Michel Boulouard ${ }^{1}$ \\ 1 UNICAEN, INSERM, COMETE, Cyceron, CHU Caen, Normandie University, 14000 Caen, France; \\ stacy.largilliere@unicaen.fr (S.L.); gerald.nee@unicaen.fr (G.N.); coolzaet.melanie@gmail.com (M.C.); \\ sophie.corvaisier@unicaen.fr (S.C.); michel.boulouard@unicaen.fr (M.B.) \\ 2 Behavioral Research Platform, Normandie University, 14000 Caen, France \\ * Correspondence: thomas.freret@unicaen.fr; Tel.: +33-2315-66877
}

check for

updates

Citation: Freret, T.; Largilliere, S.; Nee, G.; Coolzaet, M.; Corvaisier, S.; Boulouard, M. Fast Anxiolytic-Like Effect Observed in the Rat

Conditioned Defensive Burying Test, after a Single Oral Dose of Natural Protein Extract Products. Nutrients 2021, 13, 2445. https://doi.org/ $10.3390 /$ nu13072445

Academic Editor: Panagiota Mitrou

Received: 8 June 2021

Accepted: 14 July 2021

Published: 17 July 2021

Publisher's Note: MDPI stays neutral with regard to jurisdictional claims in published maps and institutional affiliations.

Copyright: (c) 2021 by the authors. Licensee MDPI, Basel, Switzerland. This article is an open access article distributed under the terms and conditions of the Creative Commons Attribution (CC BY) license (https:// creativecommons.org/licenses/by/ $4.0 /)$.

\begin{abstract}
Anxiety appears among the most frequent psychiatric disorders. During recent years, a growing incidence of anxiety disorders can be attributed, at least in part, to the modification of our eating habits. To treat anxiety disorders, clinicians use benzodiazepines, which unfortunately display many side effects. Herein, the anxiolytic-like properties of two natural products $(\alpha \mathrm{S} 1-$ casein hydrolysate and Gabolysat ${ }^{\circledR}$ ) were investigated in rats and compared to the efficacy of benzodiazepine (diazepam). Thus, the conditioned defensive burying test was performed after a unique oral dose of $15 \mathrm{mg} / \mathrm{kg}$, at two time-points (60 min and then $30 \mathrm{~min}$ post oral gavage) to show potential fast-onset of anxiolytic effect. Both natural products proved to be as efficient as diazepam to reduce the time rats spent burying the probe (anxiety level). Additionally, when investigated as early as 30 min post oral gavage, Gabolysat ${ }^{\circledR}$ also revealed a fast-anxiolytic activity. To date, identification of bioactive peptide, as well as how they interact with the gut-brain axis to sustain such anxiolytic effect, still remains poorly understood. Regardless, this observational investigation argues for the consideration of natural compounds in care pathway.
\end{abstract}

Keywords: fish protein hydrolysate; anxiety; burying test; rodent

\section{Introduction}

Anxiety disorders are among the most prevalent and disabling psychiatric disorders worldwide [1]. Currently, on the market anxiolytic drugs are mostly benzodiazepine or benzodiazepine-like agents, which particularly target the GABAergic system. Unfortunately, their use is not harmless and requires caution and vigilance. Indeed, a lifethreatening anxiety rebound effect may appear when withdrawal of benzodiazepine is too rapid [2-4]. Furthermore, benzodiazepines display significant side effects and drug interactions [5]. Risk-taking behavior have been observed under benzodiazepines prescription [6,7], together with impaired cognition, mobility and driving skills, as well as increased fall risk [8]. Additionally, if their consumption lasts for a long period (usually considered as 3 months), GABAergic medications might create a tolerance and dependence [5]. Finally, remote adverse effects have more recently been suspected, notably with an increased risk, to develop an Alzheimer's disease [9].

In view of the risks associated with benzodiazepine intake, intense preclinical and clinical research were carried out to identify/develop new therapeutic strategies for the management of anxiety disorders. Therefore, anxiolytic drugs free of GABAergic action (such as buspirone) or even anti-depressant drugs (such as Selective Serotonin/Norepinephrine Reuptake Inhibitors) have been proposed as a substitute. Although they might be used routinely to cure general anxiolytic disorders, they are unfortunately devoid of fast-acting 
effects. In addition, they may lack therapeutic efficacy and/or display important side effects. Thus, apart from only a few drug developments and/or repurposing of some antidepressant drugs, fast-acting, efficient and safe therapeutic alternatives are scarce [10].

Surprisingly, hope for a new therapeutic strategy could come from diet supplements. Indeed, they are increasingly considered as a natural alternative to treat-or to manageanxiety disorders [11]. This assumption comes, at least in part, from an observed close relationship (that some would qualify as a causal relationship) between changes in eating habits (mostly in Western countries) and the occurrence of anxiety disorders (associated or not with sleep disturbances) [12]. As a consequence, increasing efforts have been made in the search for natural, non-chemical, diet supplements with anxiolytic-like effect. Notably, natural peptides extracted from animal proteins appear as promising candidates. Thus, several interesting results were reported from experiments conducted with the milk-derived $\alpha S 1$-casein hydrolysate or with the fish protein hydrolysate. In fact, under a chronic oral administration regimen, both hydrolysates demonstrated anxiolytic-type properties in rodents (both mice and rats [13-17]), but also in several other animal species such as cats and dogs [18-21]. A few investigating works in humans have also been published $([22,23]$, see also for review [24]). For instance, level of state anxiety-assessed by the STAI test-was reduced in young adult students aged 18 to 25 after 1 week of supplementation with fish protein hydrolysate [25]. Similarly, 30 days of daily administration of $\alpha$ S1-casein hydrolysate $(150 \mathrm{mg})$ appeared efficient to relieve 63 women suffering from stress-related symptoms [23]. Of note, treatment efficiency was in this work evaluated through a newly constructed questionnaire on a mix of two previously published ones (Hamilton Anxiety scale and Ferreri Anxiety Rating Diagram). Nevertheless, other stress-related physiological parameters seem to benefit from oral intake regimen of hydrolysates. Indeed, a dampening effect in stress-induced variations was also observed on different physiological parameters, such as stress hormone level (corticosterone) or systolic blood pressure [22].

To further examine underlying mechanisms, several preclinical investigations have been performed and each reported an anxiolytic effect either with one or the other natural hydrolysates. To date, no study has compared similar experimental protocols for the onset/efficacy of different hydrolysates. In fact, as worthwhile it can be, such a comparison is not possible given the high level of disparities in terms of tested doses or administration regimen as well as behavioral test used. For instance, anxiolytic properties of fish protein hydrolysate were reported in the elevated plus maze and in the defensive burying test, as well as in the conditioned light extinction test. All those experiments were conducted using a chronic administration regimen, i.e., an oral gavage twice a day, for either 3 or 8 days, with doses ranging from 25 to $100 \mathrm{mg} / \mathrm{kg}$ [15,26]. In addition, when using even higher range doses (i.e., 300 and $1200 \mathrm{mg} / \mathrm{kg}$ during 5 days), biochemical experiments demonstrated that Gabolysat ${ }^{\circledR}$, a proprietary fish protein hydrolysate, displayed a diazepam-like effect on stress responsiveness of the pituitary-adrenal system and sympathoadrenal activity (with a reduced adrenaline and noradrenaline level in a stress condition and increase brain hippocampal GABA content in a non-stress condition) [13]. Conversely, when anxiolytic properties of $\alpha \mathrm{S} 1$-casein hydrolysate were investigated under an acute administration regimen, a dose effect study (from 5 to $50 \mathrm{mg} / \mathrm{kg}$ ) demonstrated that the minimal effective dose $(15 \mathrm{mg} / \mathrm{kg})$ was as efficient as diazepam $(3 \mathrm{mg} / \mathrm{kg})$ in the conditioned burying test. This beneficial effect was then observed for $60 \mathrm{~min}$ after a single oral administration $[16,17]$.

\section{Materials and Methods}

We aimed to assess and compare acute anxiolytic properties (i.e., after a single oral dose) of two compounds (Gabolysat ${ }^{\circledR}$ and $\alpha$ S1-casein hydrolysate), through a one trial burying behavioral test. This test was chosen given its high degree of face and construct validity, but also given its good pharmacological validation (predictive validity) [27] Efficacy of the tested compound was compared to a reference drug (the most frequently consumed benzodiazepine on the market, i.e., diazepam). 
Animals: All experiments were carried out in accordance with the European Communities Council Directive (63/2010) regarding the care and use of animals for experimental procedures, and they were approved by the local ethics committee (Comité d'Ethique NOrmandie en Matière d'EXpérimentation Animale, CENOMEXA, agreement number: 03-08-11/16/08-14). Aged of 8 weeks, male Wistar RjHan:WI rats were obtained from Janvier Labs (France) and pair-housed in Plexiglas cages with ad libitum access to food and water. A total number of 102 rats were necessary to perform displayed experiments. The animal facility was maintained on a controlled light-dark cycle (lights on from 7 a.m. to 7 p.m.), with a constant temperature $\left(22 \pm 2{ }^{\circ} \mathrm{C}\right)$. After 1 week acclimatization, animals were daily handled $(2 \times 5 \mathrm{~min})$ during the following week to reduce the stress induced through the restraint required for oral gavage (Figure 1).

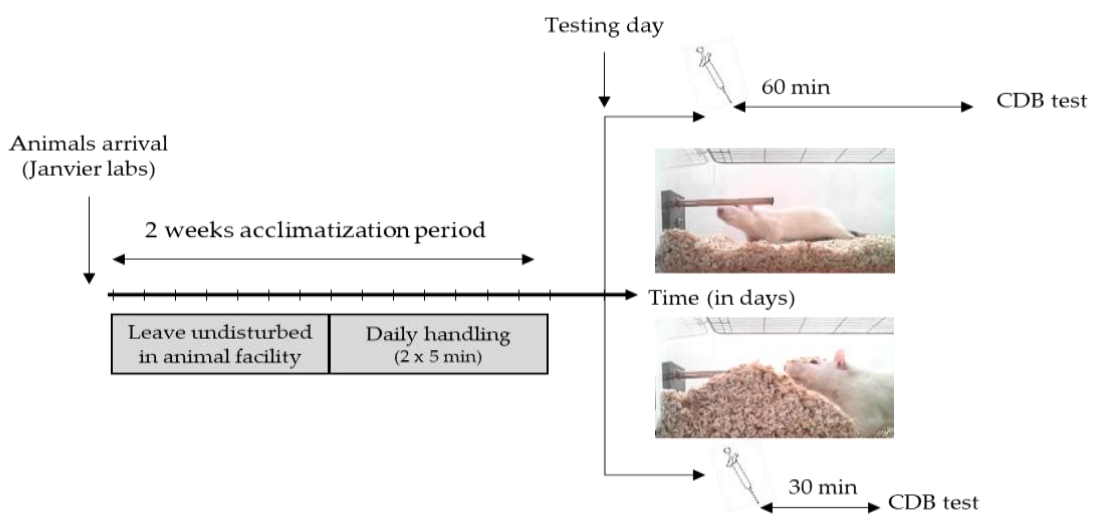

Figure 1. Experimental design. There was a 2 week acclimatization period, where animals were first left undisturbed for the first week, then handled twice daily in order to acclimate the animals to the experimenter. On the testing day, 60 or $30 \mathrm{~min}$ after an oral gavage, the Conditioned-Defense Burying (CDB) task was performed.

Group testing: $\alpha$ S1-casein hydrolysate and Gabolysat ${ }^{\circledR}$ were obtained from Ingredia ${ }^{\circledR}$ (Aras, France) and Laboratoire Dielen ${ }^{\circledR}$ (Cherbourg, France), respectively. Diazepam (Sigma, France) was used as the pharmacological benzodiazepine references substance. All compounds were solubilized in a saline $(\mathrm{NaCl}, 0.9 \%)$ mix with $1 \%$ Carboxymethylcellulose (Sigma Aldrich ${ }^{\circledR}$ ), which was used as treatment for the control group. The dose of $15 \mathrm{mg} / \mathrm{kg}$ was selected according to previous related studies [13,17]. Each compound was orally administered in a volume of $2 \mathrm{~mL} / \mathrm{kg}$ body weight.

Defensive probe-burying test: Animals were familiarized in pairs for 2 consecutive days (20 min session) with the testing room (dim lit) and apparatus which consisted in a Plexiglas acrylic cage $42.5 \times 26.6 \times 18.5 \mathrm{~cm}$ (Intelli-bio ${ }^{\circledR}$, Seichamps, France) $[28,29]$. The floor of the cage was covered with $5 \mathrm{~cm}$ of bedding material (fine wood sawdust). The following day, each rat was individually placed in the testing cage, with an electrified probe ( $7 \mathrm{~cm}$ long) emerging from one of its walls $2 \mathrm{~cm}$ above the bedding material. The latency for first approach to the probe, reflecting level of exploration behavior, was then recorded to ensure no bias interpretation of the data. Once the rat touched the probe, it received an electric shock of $0.2 \mathrm{~mA}$ (constant current shocker). All tested rats, whatever group or experiments considered, touched the probe only once and, therefore, received only a single shock. Burying behavior (pushing the sawdust ahead with rapid alternating movements of the forepaws oriented to cover the electrified probe) has been directly related with the experimental anxiety levels [29]. This behavior was constantly recorded during a $15 \mathrm{~min}$ period and in $5 \mathrm{~min}$ time slices.

Statistical analysis: All graphs displayed results as the mean \pm standard errors of mean (SEM). Statistical analyses were performed with Statview ${ }^{\circledR}$. ANOVAs were performed, followed when appropriate by post-hoc group comparison tests. The $p$-value was set at 0.05 . Bonferroni correction was applied for post-hoc multiple comparisons. 


\section{Results}

\subsection{Evaluation of Anxiolytic-Like Effect (60 min after Oral Gavage)}

One-way ANOVA of elapsed time to first approach to the probe (probe contact latency) did not reveal any statistical group differences $\left(\mathrm{F}_{(3,48)}=0.301, p=0.8245\right)$, thus, ensuring no locomotor and/or exploration behavior bias (Figure 2A). Furthermore, two-way ANOVA with a repeated measurement of burying time during the behavioral test did not reveal a group effect $\left(\mathrm{F}_{(3,48)}=1.655, p=0.1892\right)$, but a significant time effect $\left(\mathrm{F}_{(2,96)}=27.773\right.$, $p<0.0001)$ and a group $\mathrm{x}$ time interaction $\left(\mathrm{F}_{(6,96)}=3.158, p=0.0072\right)$ (Figure $2 \mathrm{~B}$ ). When focused on the first $5 \mathrm{~min}$ of the test, a significant group difference was revealed (one-way ANOVA, $\mathrm{F}_{(3,48)}=5.390$ and $\left.p=0.0028\right)$. In fact, the post-hoc test showed that all treated groups of rats (Diazepam, $\alpha \mathrm{S} 1$-casein hydrolysate as well as Gabolysat ${ }^{\circledR}$-treated animals) spent significantly less time burying the probe compared to the control group $(p=0.0162$, 0.0159 and 0.0362 , respectively). Thereafter (for the last $10 \mathrm{~min}$ of the test), probe-burying time for the control group massively dropped down (time effect: $F_{(2,24)}=52.373$ and $p<0.0001)$. No group difference can then be revealed for the last $10 \mathrm{~min}$ of the test $(p>0.05)$.

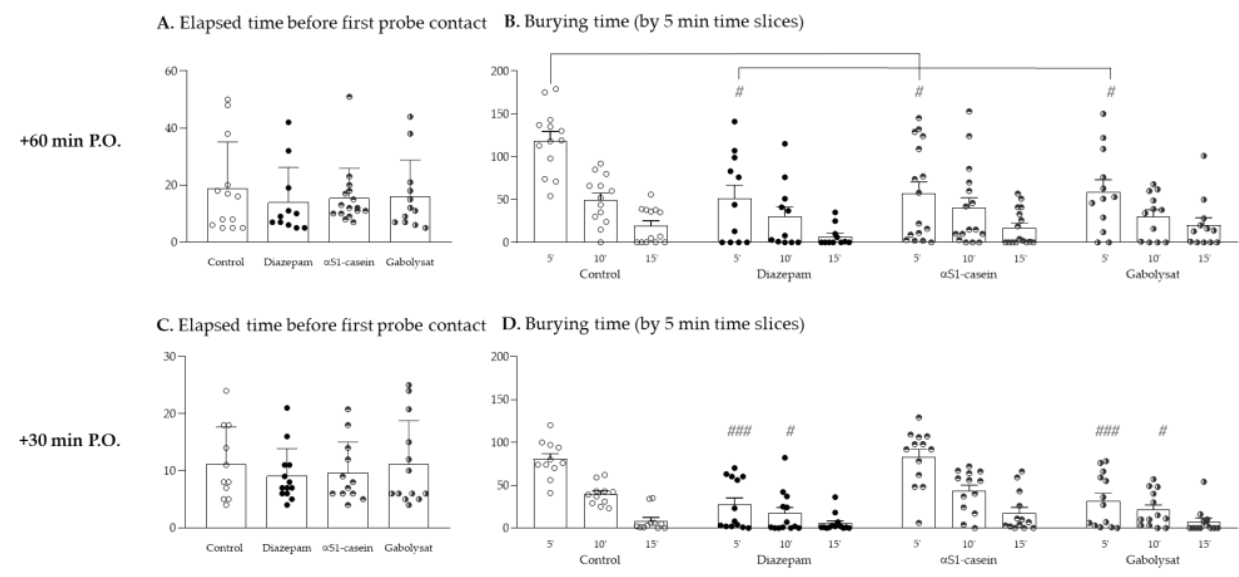

Figure 2. Conditioned behavioral test performed $60 \mathrm{~min}(\mathbf{A}, \mathbf{B})$ and $30 \mathrm{~min}(\mathbf{C}, \mathbf{D})$ after oral gavage. Figure 1 displays the latency for first contact to probe, as a control measurement of motivation/locomotor activity for all animals' groups. Figure 1 display probe-burying behavior during the test (by $5 \mathrm{~min}$ time slices), reflective of anxiety levels. A total of 102 rats were used. Groups sizes were $13,11,16$ and 12 for control, diazepam, $\alpha$ S1-casein hydrolysate and Gabolysat ${ }^{\circledR}$, respectively, when the test was performed 60 min after gavage (A,B); corresponding 13,11, 13 and 13 when test was performed $30 \mathrm{~min}$ after gavage (C,D) (ANOVA with repeated measurement, post-hoc test: \# $p<0.05$ and \#\#\# $p<0.001$ compared to respective control time).

\subsection{Evaluation of Rapid (30 min after Oral Gavage) Anxiolytic-Like Effect}

One-way ANOVA of elapsed time to first approach to the probe did not reveal any statistical group difference $\left(\mathrm{F}_{(3,46)}=0.376, p=0.7705\right)$, thus, ensuring no locomotor biases (Figure 2C). Furthermore, two-way ANOVA with a repeated measurement of burying time during the behavioral test revealed a significant group $\left(\mathrm{F}_{(3,46)}=12.749, p<0.0001\right)$ and time effect $\left(\mathrm{F}_{(2,92)}=75.708, p<0.0001\right)$, as well as a group $\mathrm{x}$ time interaction $\left(\mathrm{F}_{(6,92)}=3.779\right.$, $p=0.0021$ ) (Figure 2D). Whichever group considered, animals spent less and less time burying the probe during the behavioral test (Control group: $\mathrm{F}_{(2,20)}=53.993, p<0.0001$ and for diazepam, $\alpha S 1$-casein hydrolysate and Gabolysat ${ }^{\circledR}$-treated group: $\mathrm{F}_{(2,24)}=7.490,25.232$ and 12.089 , respectively with $p<0.001)$. The post-hoc tests showed that the global group difference relied on significantly lesser probe burying time for diazepam- and Gabolysat ${ }^{\circledR}$ treated animals compared to the control group ( $p=0.0001$ and 0.0005 , respectively). In addition, if we consider only the first or second 5 min-section of the test, one-way ANOVA of burying time revealed a significant group difference $\left(\mathrm{F}_{(3,46)}=12.981\right.$ and 4.556 , with $p<0.0001$ and $p=0.0071$, respectively). The post-hoc tests showed that both diazepam- 
and Gabolysat ${ }^{\circledR}$-treated animals spent significantly less time burying the probe compared to the control group (from 0 to 5 min test: $p<0.0001$ and $p=0.0002$; for $5-10$ min test: $p=0.0150$ and 0.0463 , respectively).

\section{Discussion}

We herein experimentally demonstrated acute anxiolytic-like properties of Gabolysat ${ }^{\circledR}$ and $\alpha \mathrm{S} 1$-casein hydrolysate [17]. Orally given at a dose of $15 \mathrm{mg} / \mathrm{kg}$ and tested in the conditioned burying task 60 min later, both natural products were as efficient as diazepam (used as benzodiazepine reference pharmacological drug) to elicit anxiolytic activity. More interestingly, when the anxiolytic-effect was assessed even as soon as $30 \mathrm{~min}$ after the oral dose, a similar efficiency (still compared to diazepam) was observed for Gabolysat ${ }^{\circledR}$. This last result demonstrates a fast onset of anxiolytic activity for Gabolysat ${ }^{\circledR}$.

Diazepam is a well-known and frequently prescribed benzodiazepine, which already experimentally demonstrated its anxiolytic activity in the conditioned burying test. Thus, its anxiolytic activity was described either when administrated intra-peritoneal (doses ranging from 0.5 to $2 \mathrm{mg} / \mathrm{kg}$ ) [29,30], or orally given $(3 \mathrm{mg} / \mathrm{kg})[16,17]$. Despite any potential differences of laboratory experimental conditions (light/dark cycle, strain, testing room environment, ... ), an anxiolytic effect of diazepam is always found, as herein. The same holds true for $\alpha \mathrm{S} 1$-casein hydrolysate. Indeed, when administered orally at $15 \mathrm{mg} / \mathrm{kg}$ and then tested $60 \mathrm{~min}$ after, $\alpha \mathrm{S} 1$-casein hydrolysate demonstrated anxiolytic properties in the conditioned burying test. Such a result is in accordance with literature data $[16,17]$, reinforcing our choice to use $\alpha \mathrm{S} 1$-casein hydrolysate as a reference natural product having demonstrated anxiolytic activity. Here, we demonstrated for the first time, that Gabolysat ${ }^{\circledR}$ —a fish proteins extract—also has rapid anxiolytic properties, as testified by the reduced probe-burying time observed in animals with acute treatment. Additionally, one can note that, whichever treatment was considered, the animals' anxiety levels (behaviorally assessed through probe-burying time measurement) were similar (no statistical difference between treated animals' groups). Thus, within the sensitivity limits of the test, we observed similar anxiolytic properties of each of the natural compounds and the benzodiazepine.

In a rat, the maximum plasmatic concentration of diazepam per os is observed at $30 \mathrm{~min}$ [31]. Hence, the experiment was conducted again with a shorten elapsed time (30 $\mathrm{min}$ ) after oral dose to attempt to observe a rapid anxiolytic effect of both natural compounds and benzodiazepine. Since the maximum plasma concentration of diazepam is observed $30 \mathrm{~min}$ after oral gavage, this was taken as the new elapsed time to evaluate anxiolytic properties. Thus, we demonstrated for the first time to the best of our knowledge, that diazepam — but also Gabolysat ${ }^{\circledR}$ — have rapid anxiolytic properties. This was testified by the decreased probe-burying behavior during the first $10 \mathrm{~min}$ of the test, performed only 30 min after oral dose. This last finding regarding the fast onset of Gabolysat ${ }^{\circledR}$ could draw clinicians' attention as it might find application in several disorders (such as sleep anxiety and insomnia) or even psychiatric pathologies, such as depression. Indeed, depression, for instance, displays a 57\% rate to co-occur with one anxiety disorder. Antidepressants prescribed so far, have revealed to be moderately efficient. This is firstly because some patients do not respond to treatment, and then because the average time to achieve remission for those who are sensitive to it is approximately 7 weeks [32]. Thus, natural products such as Gabolysat ${ }^{\circledR}$ — provided they are devoid of toxicity — may offer a therapeutic adjuvant during the first phase of treatment. So far, no side effect was reported in rodents after chronic (5 days) oral treatment of high doses of Gabolysat ${ }^{\circledR}$ (dose ranging from 300 to $1200 \mathrm{mg} / \mathrm{kg}$ ) [13].

Beyond toxicity, the mechanisms underlying anxiolytic activity observed after an oral dose of those two natural compounds still remains unknown. Given the different behavioral profile observed in our study, one might imagine that their mechanisms may slightly diverge. Among possible mechanisms, a direct action on central GABAergic and/or serotonergic transmission, as well as modulatory role on corticotrope axis have shown 
preliminary results $[13,33]$. However, one exciting hypothesis recently emerged from current ongoing research on microbiota-gut-brain axis functioning. Indeed, gut peptides were recently evoked as important regulators of microbiota-gut-brain signaling in health and stress-related psychiatric illnesses [34]. Further works are required to investigate how those two natural compounds might interact with microbiome and, as a consequence, on gut-brain axis functioning.

A major study limitation is the chosen route of administration. In fact, while closely related to human practice, oral gavage required animal restraint which is a stress-induced event. In addition, the technique might be harmful or induce pain (esophageal trauma, etc.), if the experimenter is not skilled in animal handling and restraint. All animals herein underwent handling/restraint by the same experimenter (with acknowledged expertise) and the animals' groups were counterbalanced across the session.

\section{Conclusions}

In conclusion, our results confirm the efficacy of $\alpha \mathrm{S} 1$-casein hydrolysate to dampen anxiety level but they also demonstrate, for the first time, the efficacity of Gabolysat ${ }^{\circledR}$ to do so. In addition, this last compound also displays a fast onset of action affording a rapid and lasting anxiolytic action. Numerous natural products are marketed for behavior therapy, but very few have demonstrated any evidence of efficacy. Additionally, as both natural products were described as being devoid of any major side effects, they appear as powerful natural alternative solutions to benzodiazepine drugs and to their constraints of use.

Author Contributions: The authors' responsibilities were as follows: Conceptualization, M.B. and T.F.; formal analysis, investigation and data curation, S.L., M.C., G.N. and S.C.; writing-original draft preparation and editing, T.F. All authors have read and agreed to the published version of the manuscript.

Funding: This research received no external funding.

Institutional Review Board Statement: All experiments were carried out in accordance with the European Communities Council Directive (63/2010) regarding the care and use of animals for experimental procedures, and they were approved by the local ethics committee (Comite d'Ethique NOrmandie en Matière d'EXpérimentation Animale, CENOMEXA, agreement number: 03-08-11/16/08-14).

Informed Consent Statement: Not applicable.

Data Availability Statement: The data presented in this study are available on request from the corresponding author.

Acknowledgments: Diet complement $\alpha \mathrm{S} 1$-casein hydrolysate and Gabolysat ${ }^{\circledR}$ was kindly given by INGREDIA and DIELEN, respectively. Additionally, authors wish to warmly thank Miss Nicole Turnbull for proofreading the manuscript, spelling corrections and editing English.

Conflicts of Interest: The authors declare no conflict of interest. DIELEN and INGREDIA had no role in the design of the study; in the behavioral analyses, or interpretation of data; in the writing of the manuscript; or in the decision to publish the results.

\section{References}

1. Murrough, J.W.; Yaqubi, S.; Sayed, S.; Charney, D.S. Emerging drugs for the treatment of anxiety. Expert Opin. Emerg. Drugs 2015, 20, 393-406. [CrossRef]

2. Bandelow, B.; Michaelis, S.; Wedekind, D. Treatment of anxiety disorders. Dialogues Clin. Neurosci. 2017, $19,93-107$.

3. Fluyau, D.; Revadigar, N.; Manobianco, B.E. Challenges of the pharmacological management of benzodiazepine withdrawal, dependence, and discontinuation. Ther. Adv. Psychopharmacol. 2018, 8, 147-168. [CrossRef]

4. Lader, M.; Kyriacou, A. Withdrawing Benzodiazepines in Patients with Anxiety Disorders. Curr. Psychiatry Rep. 2016, 18, 8. [CrossRef]

5. Votaw, V.R.; Geyer, R.; Rieselbach, M.M.; McHugh, R.K. The epidemiology of benzodiazepine misuse: A systematic review. Drug Alcohol Depend. 2019, 200, 95-114. [CrossRef] [PubMed]

6. Deakin, J.B.; Aitken, M.R.; Dowson, J.H.; Robbins, T.W.; Sahakian, B.J. Diazepam produces disinhibitory cognitive effects in male volunteers. Psychopharmacology 2004, 173, 88-97. [CrossRef] [PubMed] 
7. Lane, S.D.; Tcheremissine, O.V.; Lieving, L.M.; Nouvion, S.; Cherek, D.R. Acute effects of alprazolam on risky decision making in humans. Psychopharmacology 2005, 181, 364-373. [CrossRef] [PubMed]

8. Olfson, M.; King, M.; Schoenbaum, M. The popularity of benzodiazepines, their advantages, and inadequate pharmacological alternatives-reply. JAMA Psychiatry 2015, 72, 624. [CrossRef]

9. Endres, J.; Graber, M.A.; Dachs, R. Benzodiazepines and Alzheimer disease. Am. Fam. Physician 2015, 91, 191-192. [PubMed]

10. Bandelow, B. Current and Novel Psychopharmacological Drugs for Anxiety Disorders. Adv. Exp. Med. Biol. 2020, 1191, $347-365$. [CrossRef]

11. Fernandez-Rodriguez, M.; Rodriguez-Legorburu, I.; Lopez-Ibor Alcocer, M.I. Nutritional supplements in Anxiety Disorder. Actas Esp. Psiquiatr. 2017, 45, 1-7.

12. Godos, J.; Currenti, W.; Angelino, D.; Mena, P.; Castellano, S.; Caraci, F.; Galvano, F.; Del Rio, D.; Ferri, R.; Grosso, G. Diet and Mental Health: Review of the Recent Updates on Molecular Mechanisms. Antioxidants 2020, 9, 346. [CrossRef]

13. Bernet, F.; Montel, V.; Noel, B.; Dupouy, J.P. Diazepam-like effects of a fish protein hydrolysate (Gabolysat PC60) on stress responsiveness of the rat pituitary-adrenal system and sympathoadrenal activity. Psychopharmacology 2000, 149, 34-40. [CrossRef]

14. Dela Pena, I.J.I.; Kim, H.J.; de la Pena, J.B.; Kim, M.; Botanas, C.J.; You, K.Y.; Woo, T.; Lee, Y.S.; Jung, J.C.; Kim, K.M.; et al. A tryptic hydrolysate from bovine milk alphas1-casein enhances pentobarbital-induced sleep in mice via the GABAA receptor. Behav. Brain Res. 2016, 313, 184-190. [CrossRef] [PubMed]

15. Messaoudi, M.; Lalonde, R.; Nejdi, A.; Bisson, J.F.; Rozan, P.; Javelot, H.; Schroeder, H. The effects of Garum Armoricum ${ }^{(G A}(G)$ on elevated-plus maze and conditioned light extinction tests in rats. Curr. Top. Nutraceutical Res. 2008, 6, 41-45.

16. Messaoudi, M.; Lalonde, R.; Schroeder, H.; Desor, D. Anxiolytic-like effects and safety profile of a tryptic hydrolysate from bovine alpha s1-casein in rats. Fundam. Clin. Pharmacol. 2009, 23, 323-330. [CrossRef]

17. Violle, N.; Messaoudi, M.; Lefranc-Millot, C.; Desor, D.; Nejdi, A.; Demagny, B.; Schroeder, H. Ethological comparison of the effects of a bovine alpha s1-casein tryptic hydrolysate and diazepam on the behaviour of rats in two models of anxiety. Pharmacol. Biochem. Behav. 2006, 84, 517-523. [CrossRef] [PubMed]

18. Landsberg, G.M.; Mougeot, I.; Kelly, S.; Milgram, N.W. Assessment of noise-induced fear and anxiety in dogs: Modification by a novel fish hydrolysate supplemented diet. J. Vet. Behav. 2015, 10, 391-398. [CrossRef]

19. Makawey, A.; Iben, C.; Palme, R. Cats at the Vet: The Effect of Alpha-s1 Casozepin. Animals 2020, 10, 2047. [CrossRef] [PubMed]

20. Tynes, V.V.; Landsberg, G.M. Nutritional Management of Behavior and Brain Disorders in Dogs and Cats. Vet. Clin. N. Am. Small Anim. Pract. 2021, 51, 711-727. [CrossRef] [PubMed]

21. Beata, C.; Beaumont-Graff, E.; Coll, V.; Cordel, J.; Marion, M.; Massal, N.; Marlois, N.; Tauzin, J. Effect of alpha-casozepine (Zylkene) on anxiety in cats. J. Vet. Behav. 2007, 2, 40-46. [CrossRef]

22. Messaoudi, M.; Lefranc-Millot, C.; Desor, D.; Demagny, B.; Bourdon, L. Effects of a tryptic hydrolysate from bovine milk alphaS1-casein on hemodynamic responses in healthy human volunteers facing successive mental and physical stress situations. Eur. J. Nutr. 2005, 44, 128-132. [CrossRef] [PubMed]

23. Kim, J.H.; Desor, D.; Kim, Y.T.; Yoon, W.J.; Kim, K.S.; Jun, J.S.; Pyun, K.H.; Shim, I. Efficacy of alphas1-casein hydrolysate on stress-related symptoms in women. Eur. J. Clin. Nutr. 2007, 61, 536-541. [CrossRef] [PubMed]

24. Phing, C.H. A Review of the Potential Efficacy of Alpha-S1-Casein Tryptic Hydrolysate on Stress and Sleep Disorder. Malays. J. Psychiatry 2016, 25, 99-109.

25. Dorman, T.B.L.; Glaze, P.; Hogan, J.; Skinner, R.; Nelson, D.; Bowker, L.; Head, D. The effectiveness of Garum armoricum (Stabilium) in reducing anxiety in college students. J. Adv. Med. 1995, 8, 193-200. [CrossRef]

26. Messaoudi, M.; Nejdi, A.; Bisson, J.F.; Rozan, P.; Javadov, H.; Lalonde, R. Anxiolytic and antidepressant-like effects of Garum Armoricum $^{\circledR}$ (GA), a blue ling fish protein autolysate in male wistar rats. Curr. Top. Nutraceutical Res. 2008, 6, 115-123.

27. De Boer, S.F.; Koolhaas, J.M. Defensive burying in rodents: Ethology, neurobiology and psychopharmacology. Eur. J. Pharmacol. 2003, 463, 145-161. [CrossRef]

28. Fucich, E.A.; Morilak, D.A. Shock-probe Defensive Burying Test to Measure Active versus Passive Coping Style in Response to an Aversive Stimulus in Rats. Bio-protocol 2018, 8, e2998. [CrossRef]

29. Treit, D.; Pinel, J.P.; Fibiger, H.C. Conditioned defensive burying: A new paradigm for the study of anxiolytic agents. Pharmacol. Biochem. Behav. 1981, 15, 619-626. [CrossRef]

30. Wilson, M.A.; Burghardt, P.R.; Ford, K.A.; Wilkinson, M.B.; Primeaux, S.D. Anxiolytic effects of diazepam and ethanol in two behavioral models: Comparison of males and females. Pharmacol. Biochem. Behav. 2004, 78, 445-458. [CrossRef]

31. Gong, W.; Liu, S.; Xu, P.; Fan, M.; Xue, M. Simultaneous Quantification of Diazepam and Dexamethasone in Plasma by HighPerformance Liquid Chromatography with Tandem Mass Spectrometry and Its Application to a Pharmacokinetic Comparison between Normoxic and Hypoxic Rats. Molecules 2015, 20, 6901-6912. [CrossRef] [PubMed]

32. Gaynes, B.N.; Warden, D.; Trivedi, M.H.; Wisniewski, S.R.; Fava, M.; Rush, A.J. What did STAR*D teach us? Results from a large-scale, practical, clinical trial for patients with depression. Psychiatr. Serv. 2009, 60, 1439-1445. [CrossRef]

33. Mizushige, T.; Sawashi, Y.; Yamada, A.; Kanamoto, R.; Ohinata, K. Characterization of Tyr-Leu-Gly, a novel anxiolytic-like peptide released from bovine alphaS-casein. FASEB J. 2013, 27, 2911-2917. [CrossRef] [PubMed]

34. Lach, G.; Schellekens, H.; Dinan, T.G.; Cryan, J.F. Anxiety, Depression, and the Microbiome: A Role for Gut Peptides. Neurotherapeutics 2018, 15, 36-59. [CrossRef] [PubMed] 